\title{
Spatial-temporal Correlation of Dengue Fever and Climatic Variables in the City of
}

\section{São Paulo, Brazil}

Correlação espaço-temporal da dengue e variáveis climáticas na cidade de São Paulo, Brasil

Correlación espacio-temporal del dengue y las variables climáticas en la ciudad de São Paulo,

Brasil

Received: 02/17/2021 | Reviewed: 02/24/2021 | Accept: 02/25/2021 | Published: 06/03/2021

Marcio Luis Valença Araújo

ORCID: https://orcid.org/0000-0003-2376-0160 Instituto Federal de Educação Ciência e Tecnologia da Bahia, Brasil

E-mail: marcioaraujo@ifba.edu.br

Aloísio Nascimento Filho

ORCID: https://orcid.org/0000-0002-5601-8459

Faculdades Senai Cimatec, Brasil

E-mail: aloisio.nascimento@gmail.com

Antônio Cordeiro

ORCID: https://orcid.org/0000-0003-1455-5309

Faculdades Senai Cimatec, Brasil

E-mail: antonio.cordeiro@gmail.com

Renelson Sampaio

ORCID: https://orcid.org/0000-0003-1022-5732

Faculdades Senai Cimatec, Brasil

E-mail: renelson.sampa@gmail.com

Marcelo Moret

ORCID: https://orcid.org/0000-0003-0051-6309

Faculdades Senai Cimatec, Brasil

E-mail: mamoret@gmail.com

Raphael Rosário

ORCID: https://orcid.org/0000-0001-7617-7476

Universidade Federal da Bahia, Brasil

E-mail: phaoso@gmail.com

José Garcia Vivas Miranda

ORCID: https://orcid.org/0000-0002-7752-8319

Universidade Federal da Bahia, Brasil E-mail: vivasm@gmail.com

Marcio Macedo

ORCID: https://orcid.org/0000-0003-2729-7193

Universidade Federal da Bahia, Brasil

E-mail: marciocfmacedo@ hotmail.com

Eduardo Jorge

ORCID: http://orcid.org/0000-0002-8597-5805

Universidade do Estado Bahia, Brasil

E-mail: emjorge1974@gmail.com

Hugo Saba

ORCID: https://orcid.org/0000-0001-8402-6416

Universidade do Estado Bahia, Brasil

E-mail: hugosaba@gmail.com

\begin{abstract}
This paper studies the association between dengue cases and climatic variables in the city of São Paulo, Brazil, in the period from 2001 to 2011. The main hypothesis is that climatic conditions, such as precipitation, humidity and temperature, are all correlated to the dengue spread in São Paulo. Randomization and Spearman rank correlation are applied over the collected dataset, and the estimated results show that only a higher temperature is correlated to an increase in the notification of new dengue cases in São Paulo, further reinforcing the fact that the Aedes aegypti mosquito is known to survive in distinct climatic conditions, greatly adapting itself to urban environments.
\end{abstract}

Keywords: Correlation; Computational model; Epidemic disease. 


\section{Resumo}

Este trabalho estuda a associação entre casos de dengue e variáveis climáticas na cidade de São Paulo, Brasil, no período de 2001 a 2011. A principal hipótese é que as condições climáticas, como precipitação, umidade e temperatura, estão todas relacionadas à dengue disseminada em São Paulo. A randomização e a correlação de Spearman são aplicadas sobre o conjunto de dados coletado, e os resultados estimados mostram que apenas uma temperatura mais alta está correlacionada a um aumento na notificação de novos casos de dengue em São Paulo, reforçando ainda mais o fato de que o mosquito Aedes aegypti é conhecido por sobreviver em condições climáticas distintas, adaptando-se enormemente aos ambientes urbanos.

Palavras-chave: Correlação; Doenças epidêmicas; Modelo computacional.

\section{Resumen}

Este trabajo estudia la asociación entre casos de dengue y variables climáticas en la ciudad de São Paulo, Brasil, en el período de 2001 a 2011. La principal hipótesis es que las condiciones climáticas, como precipitación, humedad y temperatura, están correlacionadas con el dengue. difundido en São Paulo. La aleatorización y la correlación de rango de Spearman se aplican sobre el conjunto de datos recopilados, y los resultados estimados muestran que solo una temperatura más alta se correlaciona con un aumento en la notificación de nuevos casos de dengue en São Paulo, lo que refuerza aún más el hecho de que se sabe que el mosquito Aedes aegypti sobrevive en distintas condiciones climáticas, adaptándose en gran medida a los entornos urbanos.

Palabras clave: Correlación; Enfermedad epidémica; Modelo computacional.

\section{Introduction}

Epidemics are well known to be characterized by a sudden increase in the number of new cases and even deaths caused by a disease in a particular region of the world. Examples such as the Ebola virus in Africa (Pourrut, et al. 2005), the influenza A (H1N1) in Europe (Neumann \& Kawaoka, 2009), and the dengue in America (Araújo, et al. 2018, Nascimento Filho, et al. 2018, Saba, et al. 2018, Zambrano, et al. 2019) are threats to the communities around the world, mainly because some of those infectious diseases are highly transmissible and may even lead to fatal cases. Currently, one of the major epidemics plaguing societies on different continents is dengue. This disease has emerged as a worldwide problem since the 1950s. Although dengue rarely occurs in the continental United States, it is endemic in Puerto Rico and many popular tourist destinations in Latin America, Southeast Asia and the Pacific Islands (CDC, 2020, Halstead, 2006).

Dengue is a typical viral infectious disease in tropical and subtropical areas of the world, generally where climatic and socio-environmental conditions are favourable to its spread (Halstead, 2007). Because it is an arbovirus, this disease is spread by two species of mosquitoes: Aedes aegypti (the main vector of transmission) and Aedes albopictus. The mosquito is infected by a virus, which presents one of the four consolidated serotypes: DENV1, DENV2, DENV3, and DENV4, although one study has indicated the emergence of the fifth serotype of dengue, DENV5 (Mustafa, et al. 2015). Aedes aegypti also transmits four other diseases: yellow fever, malaria, chikungunya and zika.

The epidemiological cycles of dengue fever in Brazil show annual oscillations due to environmental or seasonal changes. Thus, in addition to being closely associated with socio-environmental and socioeconomic conditions, epidemiological cycles of dengue fever may also be linked to the variation of the climatic conditions of an environment, even though some studies have already reported that the Aedes aegypti has great resistance to variations in temperature and other climatic variables (Reinhold, Lazzari \& Lahondère, 2018).

São Paulo is the city with the highest population density in Brazil. According to the Brazilian Institute of Geography and Statistics (IBGE, 2020), São Paulo has an estimated population of 12,325,232 in 2020, a total area of approximately 1,521 square kilometers, and a population density of 7,398.26 people per square kilometers. The climate of this city is tropical, with summer rains, average annual temperatures between $19{ }^{\circ} \mathrm{C}$ and $27{ }^{\circ} \mathrm{C}$ and a rainfall index of $1,317 \mathrm{~mm}$. In São Paulo, all the seasons of the year can be experienced in a single day. The relief of São Paulo is qualified by plains, plateaus, hills, 
mountains, and depressions. The main problems that affect the city regarding abiotic factors are: air pollution, deforestation, water pollution, and soil pollution.

In this work, we aim to evaluate whether an increase in the new cases of dengue fever has a correlation with climatic variables, such as precipitation, humidity and temperature. To do so, we make use of data collected in the city of São Paulo, Brazil, since this city is the one with the highest population density of Brazil, as previously stated in this paper, and also because with an annual temperature that ranges between $19^{\circ} \mathrm{C}$ and $27{ }^{\circ} \mathrm{C}$, a precipitation average of $110 \mathrm{~mm}$ per month and a high humidity, mainly in the summer, the city of São Paulo, Brazil has appropriate climatic conditions for mosquito dissemination. In this sense, we believe that the results of this research are useful to guide the decision-making process of local governments, with respect to the public policies to combat the dengue fever in São Paulo, Brazil, and we also aim to stimulate the evaluation of such correlations in other regions around the world that are affected by the infectious disease of dengue fever.

\section{Methodology}

The methodology applied in this study sought to understand how the phenomenon of growth of notified cases of dengue in the federal system of diseases, may be related to local climatic conditions. Thus, we sought to correlate the growth of cases, and their seasonality, with the historical series of climatic conditions. The outbreaks and epidemic moments of dengue in São Paulo, may be related to climatic variables.

\subsection{Dengue Cases}

Figure 1 shows data from daily reports of dengue fever cases in São Paulo, Brazil, as recorded by the Brazilian Diseases Notification System (SINAN). There were 37,291 reports of dengue fever cases in the period from 2001 to 2011 in São Paulo. As can be seen in Figure 1, the day of May 4, 2010 had 252 notifications registered in SINAN, the highest number of daily notifications found in the time series shown in Figure 1. This autumn day recorded $10.8 \mathrm{~mm}$ of rainfall, an average temperature of $18.9{ }^{\circ} \mathrm{C}$ and an average relative humidity of 94.5\%. In São Paulo, between 2001 and 2011, the day with the lower average temperature was July 28,2001 , with $8.76{ }^{\circ} \mathrm{C}$ and the day with the highest average temperature was March 2, 2009 , with $28.48{ }^{\circ} \mathrm{C}$. The epidemic waves registered in São Paulo were concentrated from April to June. In the years 2002, 2007, 2010, and 2011, the respective annual incidence rates of dengue fever were 50.37, 49.11, 90.88 and 58.77 per 100,000 inhabitants. In 2010, this rate presented its maximum value and was the highest incidence coefficient recorded during the study. The mean number of cases in the period studied was between 3,189 and 3,390. The year 2010 was out of the norm of the other years with 10,227 notifications of dengue fever cases. 
Figure 1: Daily notifications of cases of dengue fever in São Paulo, Brazil between 2001 and 2011.

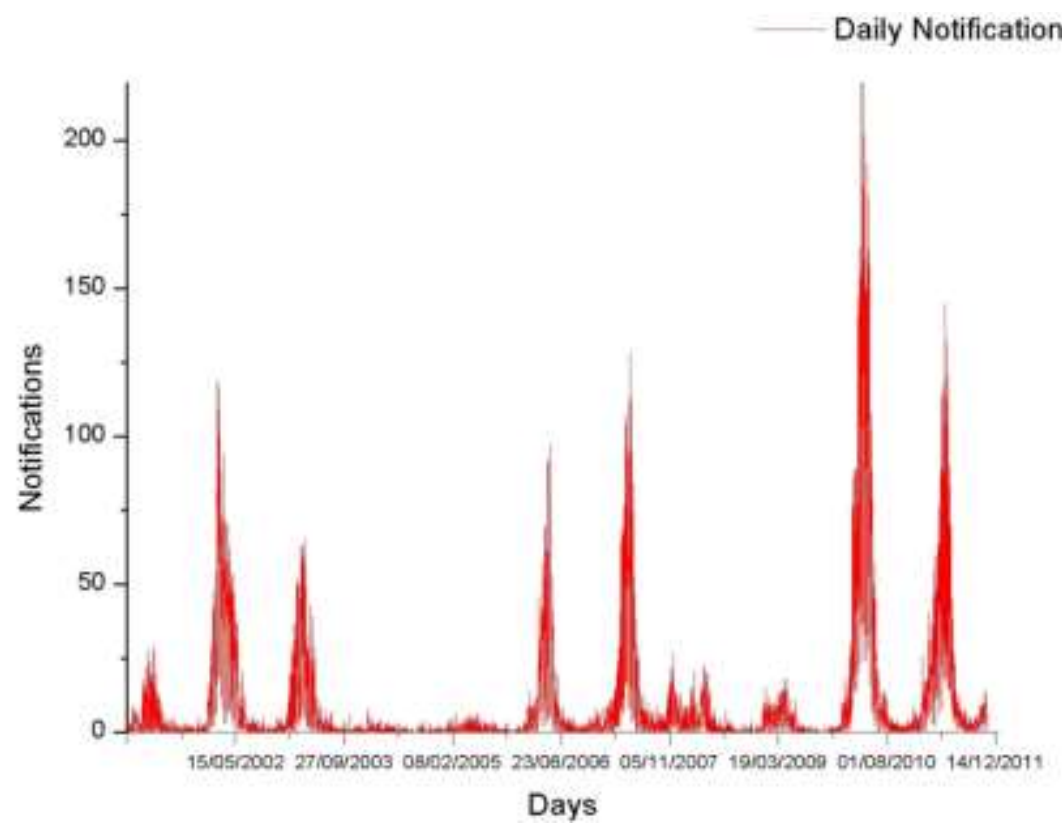

Source: Author.

\subsection{Climate Variables}

São Paulo is a city in Brazil with a high incidence of rains along the year. Some periods of high precipitation are concentrated in the spring, but mainly occurring in the summer, between the months of December to February, with hot days and storms. On the other hand, the minimum values of precipitation occur from June to August (winter). Summer rains make environments favourable for egg development and larvae, and in the period immediately after autumn there is an increase in cases, as the rains stop, but there is still a hot and humid climate ideal for development of Aedes aegypti. The sanitation conditions of urban areas are one of the complicating elements in this process, since there is an accumulation of exposed containers that favour the breeding of the mosquito.

\subsection{Data Collection}

To conduct our research, we have extracted data from SINAN and the Meteorological Database for Teaching and Research (BDMEP), corresponding to the period between 2001 and 2011. As mentioned in Section 1, the city of São Paulo, Brazil was selected for our analysis due to its high population density and favorable climatic conditions for the spread of the dengue fever. We have extracted daily data of precipitation $(\mathrm{mm})$, temperature $\left({ }^{\circ} \mathrm{C}\right)$ and humidity $(\%)$ of São Paulo between 2001 and 2011 from the BDMEP database (INMET, 2020), by using a meteorological station in São Paulo, named MIR de SANTANA, whose World Meteorological Organization code is 83781.

To better understand the behaviour of dengue fever in São Paulo, Figure 2 shows the daily dengue fever notifications versus the daily measurement of the climate variables. In Figure 2a, the peaks of dengue fever notifications coincide with the peaks of high temperatures. In Figure $2 b$, the increase of notifications of cases are mostly preceded by rainy periods. In Figure $2 c$, it is noted that in the periods of lower humidity, fewer notifications occur. 
Figure 2: Daily reports of cases of dengue fever (in red) versus daily reports (blue) of (a) temperature, (b) precipitation and (c) humidity as measured in São Paulo, Brazil, in the period between 2001 and 2011.

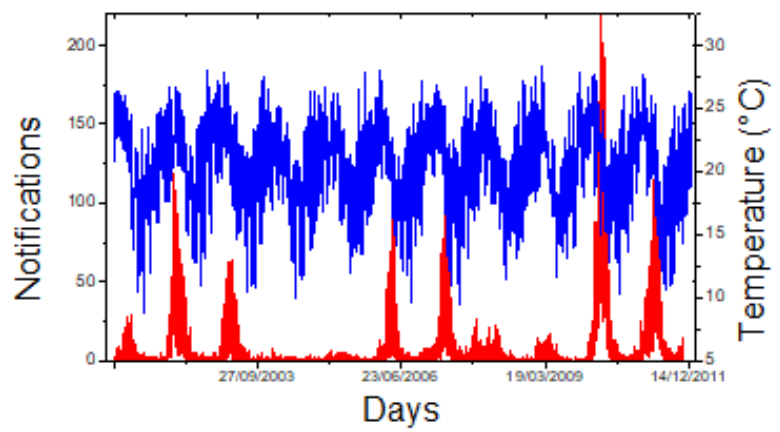

(a)

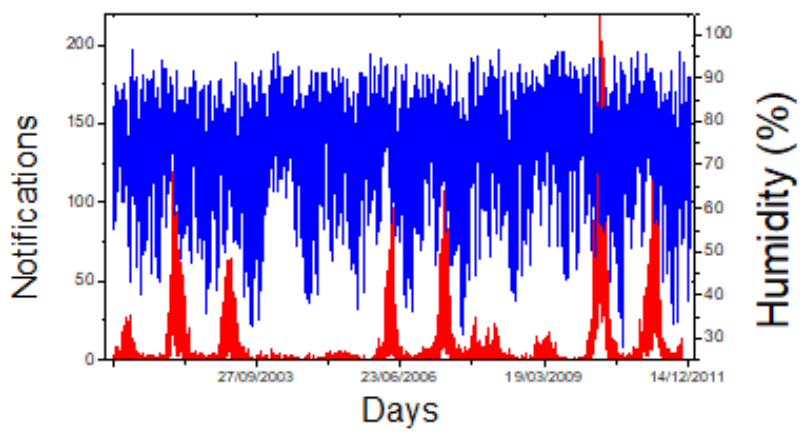

(c)

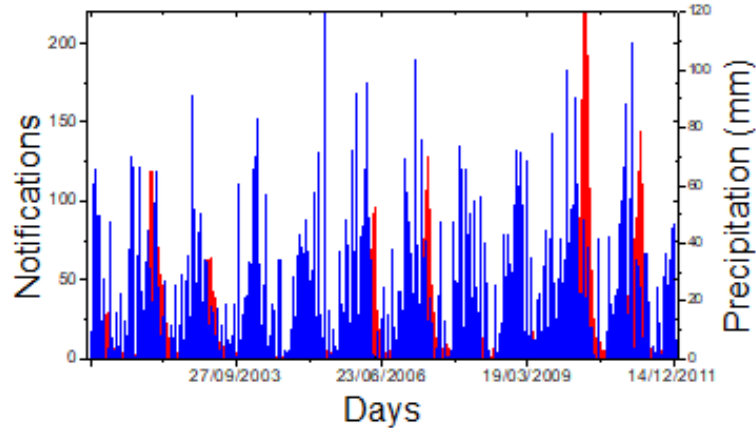

(b)

Source: Author.

\subsection{Statistical Analysis}

In terms of statistical analysis, we used randomization on the basis of Monte Carlo simulation (Manly, 2016) and Spearman correlation to measure whether and how much the discrete variables of daily reports of new cases of dengue fever, measured temperature, precipitation, and humidity in São Paulo, Brazil is correlated, and whether the reported results are statistically significant.

\section{Results and Discussion}

In this section, we analyze the behaviour of the correlation between different climatic variables and dengue fever cases. Figure 3 depicts the randomization test results with two sequences of random numbers. In this sense, Spearman correlation randomization was performed 100,000 times with data interactions. We recall that the green bar is the result of the correlation between daily dengue fever notification and one of the climatic variables. The red bar represents the distribution of randomized data. For all the randomization tests, we used the default threshold of $p<0.05$ as a parameter of significance level. 
Figure 3: Results of randomization between daily reports of new cases of dengue fever versus daily measurements of (a) temperature, (b) precipitation, and (c) humidity.

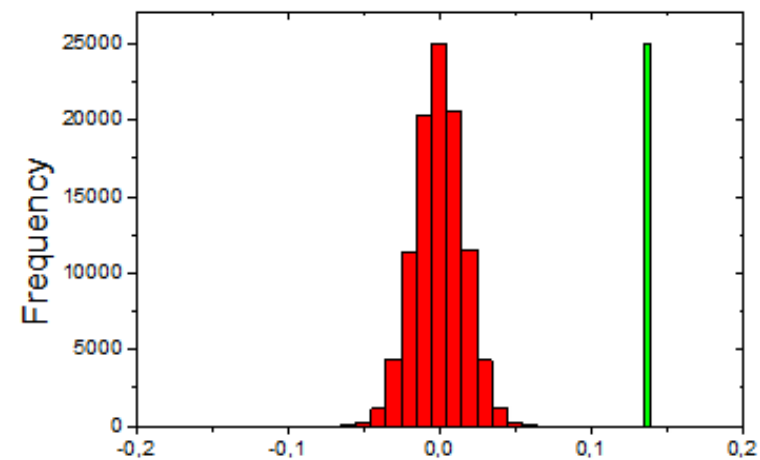

(a)

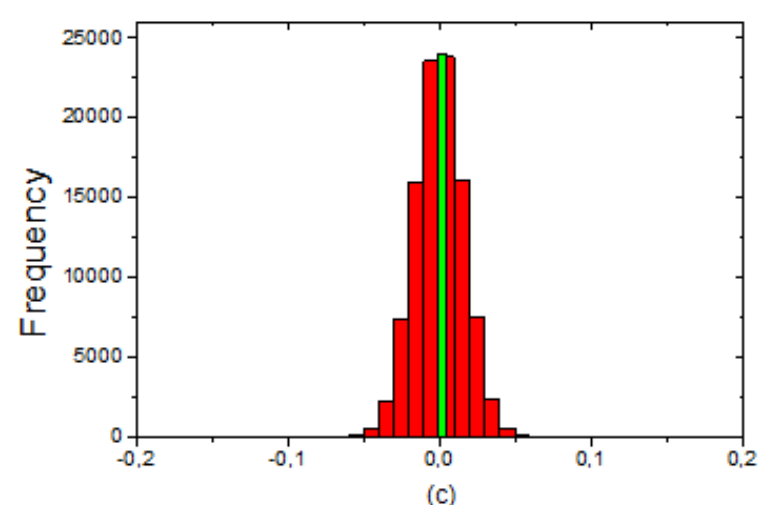

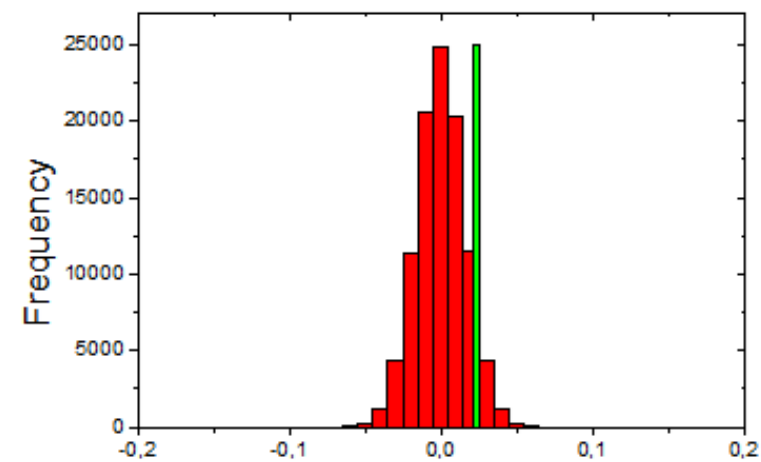

(b)

Randomized Data Spearman

Source: Author.

Figure 3a shows a comparison between the distribution of Spearman correlation indices of the random outputs with the correlation value obtained from the original data of daily notifications versus the temperature in São Paulo. As a result, we obtained $p=0$ as the significance level and $14 \%$ as the correlation coefficient of Spearman. Thus, it was observed that there is a significant correlation between the incidence of dengue fever and the mean temperature in São Paulo.

Figure $3 \mathrm{~b}$ shows the distribution of correlation values found for randomizations and correlation of the original data of daily reports versus precipitation. As a result, we obtained $p=0.0948$, which indicates that the results presented in the randomization are insufficient to indicate a significant relationship between the variables tested. In this case, we found $2 \%$ as the correlation coefficient of Spearman.

Figure 3c shows the distribution of correlation values found for randomizations and correlation of the original data of daily notifications versus humidity. It also shows that the randomization results are insufficient to assert a significant relationship between the variables tested. A negative probability was recorded with $0 \%$ from the original correlation, that is, none of the results with correlations and obtained a $p=0.5111$. Thus, in Figures $3 \mathrm{~b}$ and $3 \mathrm{c}$, no correlation was observed between the daily reports of dengue fever cases versus precipitation and humidity.

The behaviour observed in Figure 3a suggests a correlation between an increased number of reports of dengue fever in days with higher temperatures. The behaviour observed in Figure $3 \mathrm{~b}$ suggests that the peaks of reports of dengue fever cases precede rainy periods. However, this pattern could not be statistically validated by the randomization test, which suggests a weak correlation between the two variables (reports of dengue fever cases and precipitation). Finally, Figure $3 \mathrm{c}$ shows that in 
periods of low humidity, few cases of dengue fever are reported. The randomization test showed there is no correlation between reports of dengue fever cases and humidity, that is, the relationship is random.

\section{Conclusion}

Several diseases that are restricted to tropical areas, are associated with temperature, so that they could hypothetically be affected by changes in climate. Moreover, temperature is linked to many other non-parasitic contagious diseases, such as yellow fever and other arthropod-borne viral diseases, including dengue fever. Some studies (Keating, 2001) have already stated that temperature and rainfall influences vector survival, vector procreation, changes in vector distribution and vector density. However, recently, dengue fever cases have been reported in the Iberian peninsula. Thus, dengue fever has spread to previously unregistered regions, such as the European continent, showing the vector's high adaptability (Akiner, et al. 2016). In this way, this disease can be considered a world-scale problem.

In this paper, we have shown that the spread of dengue fever in São Paulo follows unclear behaviours. Since its climatic variables are dynamic, with rapid climatic transitions in the day, the dengue fever spread is not governed by season. A possible reason for the dengue fever spread is the adaptivity of the Aedes aegypti mosquito in urban environments. This type of mosquito has been shown to survive regardless of the most common climatic conditions seen in São Paulo. Thus the hypothesis of an association between reports of dengue fever cases and temperature can be accepted. However, no statistical significance was found for the correlation between an increase in the number of dengue fever cases, and daily measurements for humidity and precipitation variables.

It is interesting, as a future work, to study the impact of climatic variables in epidemic years, as well as how the climate impacts the growth of cases in different biomes in the state of São Paulo.

\section{Acknowledgments}

This work received financial support from the National Counsel of Technological and Scientific Development CNPq (grant numbers 458549/2014-2, 448303/2014-0, 304454/2014-1, 310133/2016-5, 431990/2018-2 and 313423/2019-9) and the National Petroleum Agency (ANP) PRH55 FINEP (Process Number: 486100833602013).

\section{References}

Akiner, M. M., Demirci, B., Babuadze, G., Robert, V., \& Schaffner, F. (2016). Spread of the invasive mosquitoes Aedes aegypti and Aedes albopictus in the Black Sea region increases risk of chikungunya, dengue, and Zika outbreaks in Europe. PLoS neglected tropical diseases, 10 (4), e0004664.

Araújo, M. L. V., Miranda, J. G. V., Sampaio, R., Moret, M. A., Rosário, R. S., \& Saba, H. (2018). Nonlocal dispersal of dengue in the state of Bahia. Science of the Total Environment, 631, 40-46.

Centers for Disease Control, Dengue (2020https://www.cdc.gov/dengue/.

Halstead, S. B. (2006). Dengue in the Americas and Southeast Asia: do they differ? Revista panamericana de salud publica, 20, 407-415.

Halstead, S. B. (2007). Dengue. The lancet, 370(9599), 1644-1652.

IBGE, Instituto Brasileiro de Geografia e Estatística, Population of São Paulo (2020). https://www.ibge.gov.br/cidades-e-estados/sp/sao-paulo.html.

INMET. Instituto Nacional de Metereologia (2020). http://www.inmet.gov.br/projetos/rede/pesquisa/.

Keating, J. (2001). An investigation into the cyclical incidence of dengue fever. Social science \& medicine, 53(12), $1587-1597$.

Manly, B. F. (2006). Randomization, bootstrap and Monte Carlo methods in biology. CRC press.

Mustafa, M. S., Rasotgi, V., Jain, S., \& Gupta, V. J. M. J. A. F. I. (2015). Discovery of fifth serotype of dengue virus (DENV-5): A new public health dilemma in dengue control. Medical journal armed forces India, 71(1), 67-70. 
Research, Society and Development, v. 10, n. 3, e7010313067, 2021

(CC BY 4.0) | ISSN 2525-3409 | DOI: http://dx.doi.org/10.33448/rsd-v10i3.13067

Nascimento Filho, A. S., Araújo, M. L. V., Miranda, J. G. V., Murari, T. B., Saba, H., \& Moret, M. A. (2018). Self-affinity and self-organized criticality applied to the relationship between the economic arrangements and the dengue fever spread in Bahia. Physica A: Statistical Mechanics and its Applications, 502, 619-628.

Neumann, G., Noda, T., \& Kawaoka, Y. (2009). Emergence and pandemic potential of swine-origin H1N1 influenza virus. Nature, 459(7249), 931-939.

Pourrut, X., Kumulungui, B., Wittmann, T., Moussavou, G., Délicat, A., Yaba, P., \& Leroy, E. M. (2005). The natural history of Ebola virus in Africa. Microbes and infection, 7(7-8), 1005-1014.

Reinhold, J. M., Lazzari, C. R., \& Lahondère, C. (2018). Effects of the environmental temperature on Aedes aegypti and Aedes albopictus mosquitoes: a review. Insects, 9(4), 158

Saba, H., Moret, M. A., Barreto, F. R., Araújo, M. L. V., Jorge, E. M. F., Nascimento Filho, A. S., \& Miranda, J. G. V. (2018). Relevance of transportation to correlations among criticality, physical means of propagation, and distribution of dengue fever cases in the state of Bahia. Science of The Total Environment, 618, 971-976.

Zambrano, L. I., Rodriguez, E., Espinoza-Salvado, I. A., \& Rodríguez-Morales, A. J. (2019). Dengue in Honduras and the Americas: The epidemics are back! Travel Med Infect Dis, 101456-101456. 